\title{
The Case for Youth Police Initiative
}

This book investigates the Youth Police Initiative (YPI) intervention with a comprehensive look at its effects in Boston as well as Brownsville, Brooklyn, a neighborhood that has both rich community networks and the highest crime rate in New York City. Based on a phenomenological approach, The Case for Youth Police Initiative: Interdependent Fates and the Power of Peace offers first-person narratives of youth, police, and community members in Brownsville as the YPI program was implemented.

Police shootings and other negative exchanges between community members and the police have brought heightened awareness to the volatile relations between communities and police. The North American Family Institute began the YPI in Baltimore in 2003 with the ambition of keeping vulnerable youth away from arrests, gangs, guns, violence, and fatalities. The training intervention has been replicated in several communities in the United States and beyond. The focus of YPI training is to address the dual challenge of teaching youth the skills to resolve daily conflicts with authority while also teaching police officers to have meaningful dialogue with young people. The voices of the stakeholders reveal changes in attitudes and actions from before, during, and afterYPI's implementation. A comprehensive illustration of the intervention's arc provides the reader with an in-depth, textured perspective of what it takes to prevent pernicious eruptions of tension between police and the community they are charged to serve and protect.YPI's success in addressing tensions between youth and police in Boston and Brownsville, Brooklyn, maps out a blueprint for progress in other communities.

Suitable for scholars and researchers in criminology, sociology, psychology, and social work and practitioners on the front lines, The Case for Youth Police Initiative will provoke dialogue on best practices for changing the volatile climate between police and the young people.

Nina Rose Fischer, Ph.D. is an Assistant Professor at John Jay College of Criminal Justice in the Interdisciplinary Studies Department. She has taught undergraduates and graduate students at Hunter College, CUNY in Sociology, Hunter School of Social Work, and John Jay College. She has 20 years' experience in juvenile justice as a clinician, administrator, researcher, and policy analyst. She conducted a meta-analysis for the New York State Division of Criminal Justice Services of juvenile justice re-entry and led implementation research in the jurisdictions with the highest numbers of incarcerated youth. She is Principal Investigator on two mixed methods studies. First, the Youth Police Initiative evaluation in Long Island's Hempstead and Wyandanch; Brownsville Brooklyn, New York; and Kansas City, Missouri. Second, the evaluation of the Safety First Real Drug Education for Teens harm-reduction drug-education curriculum in New York City and San Francisco, CA. She won the Andrew Weil Award for Achievement in the Field of Drug Education for that research with 800 freshmen. She authored book chapters on cross-systems work with youth involved in multiple systems and innovative interventions with youth in the juvenile justice system. She has also had an article about Youth Police Initiative pilot studies published in the Journal of Peace Psychology. 


\section{Routledge Innovations in Policing}

This series explores innovations in the field of policing and offers the latest insight into the field through research, theoretical applications, case studies, and evaluations. Famous innovations developed over the course of the late twentieth century and into the turn of the twenty-first include approaches such as community policing, "broken windows" policing, problem-oriented policing, "pulling levers" policing, third-party policing, hot spots policing, CompStat, and evidence-based policing. Some of these approaches have been successful, and some have not, while new innovations continue to arise. Improving police performance through innovation is often not straightforward. Police departments are highly resistant to change, but through such research we expect to find further refinement of our knowledge of "what works" in policing, under what circumstances particular strategies may work, and why these strategies are effective in improving police performance.

\section{Ends and Means in Policing}

John Kleinig

\section{Stress Inside Police Departments}

How the Organization Creates Stress and Performance Problems

in Police Officers

Jon M. Shane

\section{Organizational Change in an Urban Police Department} Innovating to Reform

Brenda J. Bond-Fortier

\section{The Case for Youth Police Initiative}

Interdependent Fates and the Power of Peace

Nina Rose Fischer

For more information about this series, please visit: www.routledge.com/ Routledge-Innovations-in-Policing/book-series/RIP 


\section{The Case for Youth Police Initiative}

Interdependent Fates and the Power of Peace

Nina Rose Fischer

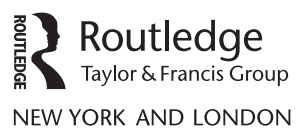


First published 2020

by Routledge

52 Vanderbilt Avenue, New York, NY 10017

and by Routledge

2 Park Square, Milton Park, Abingdon, Oxon, OXI4 4RN

Routledge is an imprint of the Taylor \& Francis Group, an informa business

(C) 2020 Taylor \& Francis

The right of Nina Rose Fischer to be identified as author of this work has been asserted by her in accordance with sections 77 and 78 of the Copyright, Designs and Patents Act 1988.

All rights reserved. No part of this book may be reprinted or reproduced or utilized in any form or by any electronic, mechanical, or other means, now known or hereafter invented, including photocopying and recording, or in any information storage or retrieval system, without permission in writing from the publishers.

Trademark notice: Product or corporate names may be trademarks or registered trademarks, and are used only for identification and explanation without intent to infringe.

Library of Congress Cataloging-in-Publication Data

Names: Fischer, Nina Rose, author.

Title: The case for Youth Police Initiative: interdependent fates \& the power of peace/Nina Rose Fischer.

Description: New York, NY: Routledge, 2020. | Includes bibliographical references and index.

Identifiers: LCCN 2020007912 (print) | LCCN 2020007913 (ebook) | ISBN 97808 I 5384748 (hardback) | ISBN 978I35I 2035 I 7 (ebook)

Subjects: LCSH:Youth and Police Initiative. | Police services for juveniles-Massachusetts-Boston-Case studies.| Police services for juveniles-New York (State)-New York-Case studies. |

Police-community relations-Massachusetts-Boston-Case studies. |

Police-community relations-New York (State)-New York-Case studies. |

Brownsville (New York, N.Y.)

Classification: LCC HV8079.25 .F54 2020 (print) | LCC HV8079.25

(ebook) |

DDC 363.2/3-dc23

LC record available at https://Iccn.loc.gov/20200079/2

LC ebook record available at https://lccn.loc.gov/20200079/3

ISBN: 978-0-8I53-8474-8 (hbk)

ISBN: 978-I-35 I-2035 I-7 (ebk)

Typeset in Bembo

by Wearset Ltd, Boldon, Tyne and Wear 


\section{Contents}

Preface

Introduction

1 Theory and Founding of YPI

2 YPI: Principal Players and Praxis

3 YPI Case Study Boston: Franklin Field

4 Youth and Police Perceptions of Each Other Pre-YPI

5 Notes From the Sessions

6 Post-YPI: Police and Youth Assess Impacts

7 Themes: Challenges to Community Police Relations

8 Themes: Overcoming Obstacles Between Youth and Police

9 What Do We Do Now?

References

Index 


\section{Preface}

\section{What Do We Do Now?}

Despite telling the officer that he had a licensed firearm in his glove compartment, black American social worker Philando Castile was shot and killed in an affluent white Minneapolis neighborhood by Latino Officer Geronimo Yanez on July 6, 2016 during a benign car stop. Similarly, the day before in Baton Rouge, Louisiana, Alton Sterling, 37-year-old black American, was killed by white police officers Howie Lake II and Blane Salamoni. Two days later, on July 8 , in response to back-to-back deaths and the cumulative fatalities of black people by police, heavily armed 25-year-old war veteran Micah Johnson shot police officers in downtown Dallas, killing five. The New York Times reported that: "He specifically set out to kill as many white officers as he could." A Facebook quote from Johnson read, "That's what they are doing to us, it's their turn." Media outlets like Fox News and the New York Post report that officers are being killed by vengeful civilians at the same rate that officers are killing civilians. Statistically, however, this is far from the truth. Police killings by civilians are lower than they have been since 1960 (Lopez, 2016). ${ }^{1}$

A close relation, 22 years old, black and Jewish male was stopped by the cops for a broken taillight in his vehicle with his white 21-year-old girlfriend. Police found a bag with fine amounts of heroin residue, arrested my close relation, brought him to a nearby jail, and confiscated his truck. He had started using heroin with his girlfriend after becoming addicted to the oxycodone prescribed for a knee injury. He spent a year in jail with no direct drug treatment except for the eventual Narcotics Anonymous meetings. The police drove the girlfriend home. Another close relation had a long-term heroin addiction that led her to live on the streets of NYC. She was never arrested, eventually received extensive drug treatment, and is living a successful life. I have witnessed police target my black family, friends, and students. I teach critical community policing at a criminal justice school to burgeoning advocates for both social justice and law enforcement. We endlessly "deconstruct" the failures of the criminal justice system, but what can we do right now? What does work? 
Gun violence and police brutality are real. What to do about volatile relations between low-income communities of color, in particular, and police is of critical importance. Activists demand justice for victims of police brutality and call for major reform and/or abolition of policing practice and policies. Police departments across the country are assessing how to better interact with community members. Significant policy, practice, and, ultimately, culture and systemic change is necessary but challenging. What can we do now?

I am queer and Jewish, from an integrated, middle-class neighborhood adjacent to Chicago. My previous experiences with police were encounters with "Officer Friendly" in elementary school, daily sexual harassment from a school resource officer in high school (I will never forget the refrain, "Oooohh I can't wait 'til you graduate"), and in my 20s, creepy cops casing lesbian bars, flailing their billy clubs around. I was also quite struck by officers' adept care and concern towards a woman we found in the Chicago street where we lived, beaten badly from domestic abuse, imploring us for help. These police were from a specially trained unit. They squatted down and looked up at her, asking what they could do to help her feel safe. They listened compassionately and drove her to a domestic violence shelter. During this same time period I witnessed a hate crime perpetrated by off-duty cops in 1997, before I became involved in Youth Police Initiative in 2004.

My girlfriend stopped to park our car on a one-lane street and the traffic behind us was forced to wait. Two men behind us got out of their car and yelled their way up to the window that we needed to keep moving. This was in the Belmont-Boystown neighborhood in Chicago, where it can take over an hour to find a parking spot. We had "scored," found a space, and continued to park the car. One of the men pulled up his shirt and pressed a badge and gun against the window. He called my black Guyanese partner the N word. He kept pointing to his gun and badge and yelling racial epithets. He pressed his face against the car window and realized that my girlfriend was a woman, and then through a spray of saliva belted: "N [word] Dyke." Still blocking traffic, my girlfriend got out of the car and stared down at him from her 6' $2^{\prime \prime}$ perch fearlessly repeating, "What are you going to do?” A cacophony of beeps came from behind his car. He scurried back to his vehicle like a frightened cockroach.

When we made the police report the officer promised us that calling it assault with a deadly weapon would be more effective than a "hate crime." He was wrong; when we reported the officers to Internal Affairs, they relayed that there was new hate crime legislation that would have elevated the status of the incident and mandated swift and certain consequence. The officers received no discipline. I wanted to know, "What can we do?"

The contrast of the trauma-informed behavior of the police responding to the woman dealing with domestic violence informed me that the type of training officers receive really matters. 


\section{An Intersectional Understanding}

We were relieved that my girlfriend did not get beaten up, shot, or killed. It is important to have an intersectional understanding of police brutality (Crenshaw, 1994; Khaleeli, 2006).There are uncounted cases of cops harassing and brutalizing queer people of color with impunity (Mogul, Richie, \& Whitlock, 2012). Not only are women of color, especially black women in low income communities, more likely to be brutalized, shot, or killed by police (Khaleeli, 2016), but so are queer people of color. Gender and sexuality add another layer of discrimination. Criminalization of queer sexuality and gender persists as a police practice rooted in anti-sodomy laws, and what were called the sumptuary laws, where if you wore more than three items of clothing not stereotypically ascribed to your gender you were unlawfully arrested (Mogul et al., 2012).

In New York State a 2003 investigation uncovered that 400 people had been arrested over a 20-year period and charged under a state law prohibiting consensual sodomy that was finally nullified in 1980. Over 296 of the arrests had been made in New York City alone (Mogul, Richie, \& Whitlock, 2015). Criminalization continues, even decades after the laws have been changed. Critically, when sexuality and gender are criminalized the people targeted by police are disproportionately of color and poor (Mogul et al., 2015).

\section{Youth Justice?}

An intersectional understanding is critical to an understanding of youth police relations. Race, class, and neighborhood compound the extent and quality of police involvement. I was a Psychiatric Social Worker through the health department in a youth detention facility in San Francisco. San Francisco is predominantly white (49\%) and Asian (33\%), but from 1997 to 2004, 85\% of incarcerated youth were black, even though black people made up only $12 \%$ of the population. Of all San Francisco black youth from 12 to 21 years old, 40\% in that time period had some contact with the justice system (CJCJ, 2007). In seven years at the facility, I saw hundreds of youth come through. Only one was white. Youth all came from the same specific low-income neighborhoods (CJCJ, 2007). Once a youth was arrested and entered the doors of detention, the cycle of incarceration began. I watched countless Probation Officers, both well- and ill-intentioned, attest that it was "for the safety" of the young person to put them back in jail. Youth were most often detained again for what are called status offenses but are really indicators that their basic rights and needs are not being attended to. Truancy is related to accessing a fair and adequate education. Curfew violation and "running away" are linked to having safe and supportive housing. Going back to jail did not help the youth access these basic needs and rights (Fischer, 2011).

I worked on B5, the unit for the most serious offenders, youth who had allegedly committed violent crimes, including homicide. Young people on B5 
were detained in single $8^{\prime} \times 8^{\prime}$ cells and were only allowed outside an hour a day for recreation, which consisted of walking in circles on a concrete square under a patch of sky. This was called a 23 and 1:23 hours in the cell and 1 hour out. Some youth had been on B5 for over two years as they awaited sentencing. I remember meeting weekly with Lawrence, a young man whom I had previously worked with for two years before he was detained again, this time for allegedly killing someone with a firearm. Lawrence suffered from acute PTSD after watching numerous family members and friends die from gun violence. ${ }^{2}$ He and I had a friendly, easy rapport and I was happy to be there to support him. However, when the guard locked me in the cell for our one-hour therapy session, being claustrophobic, my heart pounded in my throat. I had to use the breathing method I shared with him for PTSD, to keep my panic attack at bay. Lawrence stayed there for three years before he was sentenced to a penitentiary for life.

Of the youth I worked with, 30 were lost, either by homicide or to prisons. I developed an ulcer, resigned from the detention facility, and worked instead for the subsequent nine years spearheading programs, then policies, to keep youth out of jail.

I witnessed an early session of the North American Family Institute's (NAFI) Youth Police Initiative (YPI) in practice. The YPI changed my perceptions of what could happen to prevent youth from languishing in the criminal justice system. I observed the intervention address the traumatic collateral effects that arrests have on our young people, their families and communities, along with the vicarious trauma experienced by people who work in the system.

\section{Observation of YPI}

Prior to YPI I had resisted any interventions that involved bringing youth together with police. I was affected by what I saw happen to my girlfriend, my cousin, and the youth I worked with. I experienced severe cognitive dissonance, ${ }^{3}$ believing it was not safe for black and brown youth to be in any dynamic with police. If I was traumatized - a white middle class person in daily contact with the justice system as a professional-I could only imagine the outcomes for the people directly targeted by law enforcement.

Youth Police Initiative (YPI) is a five-session place-based intervention plus a graduation ceremony developed by the North American Family Institute (NAFI) in 2003 to improve police-youth relations. The Massachusetts-based non-profit partnered with community-based organizations already providing prevention and aftercare services to youth in the criminal justice system to identify youth for YPI. It is most often implemented in areas with high police surveillance. I attended my first YPI session at a public housing development in White Plains, New York in 2004. Youth were court involved and attended an aftercare program. They were paid to participate as trainers. The police were from the beat where the young men lived. In the initial three-day, three-hour 
sessions, the participants shared experiences with a trained facilitator and one officer identified as "cool" by the youth, in preparation for the subsequent two training sessions. Youth not only revealed their own encounters with police, but also the traumatic experiences of friends, family, and community members. They identified a scenario based on the most common occurrence between youth and police in their community to use as a training tool with the officers. As the youth honed their facilitation and public speaking skills, they prepared to stand and deliver both their personal stories and aspirations to the police officers in the room. A charming confident young man, Dante, ${ }^{4}$ shared the scenario that occurred with his arresting officer, who would be participating in the training. He was concerned about what it would be like confronting the officer through YPI.

On day four when the cohort of officers arrived, they first met with the NAFI facilitators alone. Officers were asked to describe the average youth they might encounter in the precinct. Negative stereotypes streamed from their lips. "Thugs," "Gangbangers," "Broken Homes," "Single Mothers," "Poor." Then they each drew a chronology on large paper that described how they became police officers, with facilitators giving police a quick tutorial in both adolescent brain development and in psychologist Abraham Maslow's hierarchy of needs theory-with needs ranging from the physiological to safety, to love and belonging, to esteem, and, at the top of the hierarchy, self-actualization. The youth then entered in a line and sat facing the officers. Young men delivered their life stories. I observed hardened officers' expressions soften as a youth with pants sagging below his waist disclosed that he was the primary caretaker for the grandmother who raised him. The officers' clenched fists opened as they listened to story after story of youth who wanted to be the first in their family to graduate high school or go to college. Each young man-one after another-received resounding applause.

Then it was the police officers' turns to tell their stories. They described being raised by grandparents or single mothers, getting into fights at school, getting beaten up in the neighborhood, being the first to graduate from high school, and so on. Much as the police officers' fists had unclenched, the youths' body language, armor forged by the generational refrain, "We can't trust the police," began to melt. For the next exercise youth and officers were asked to pair off and share their "star qualities." They communicated personal anecdotes about their lives. Afterwards, they introduced each other to the group. "This is Officer Joe, he loves baseball. His star quality is that he cares about the community." "This is John, he also loves baseball and his star quality is he takes care of his little sister."

The rest of the session and the next day were spent in role-playing scenarios and trust-building exercises. Police and youth laughed heartily as they reversed roles in the typical scenarios where they encountered each other in the community. The police gleefully enacted rowdy, rough-housing youth; youth relished their re-enactments of aggressive police force, pretend 
billy clubs in hand, guns out, with no one spared from arrest. Dante was actually able to role play the police encounter with his arresting officer, which precipitated in-depth discussion about why cops use the tactics they use, and how youth would respond better to calm and informative police communication. Youth and police giggled as they held hands in a circle and wove under each other's arms to form a human knot, then worked as an awkward jumble of limbs to untangle themselves. Police were dressed in full gear (this is standard practice for YPI) with guns and billy clubs exposed in holsters.

Youth and police put together an action plan that entailed clear, concrete steps about what they would commit to do to realize a shared vision of a safe productive community. Early evidence showed that YPI made a difference. For example, police records showed that not only was the YPI in White Plains, New York related to a reduced number of arrests, but that violence and overall negative contacts between youth and police decreased over the three years that it was implemented (Santos, 2007). Seeing was believing. After profound cognitive dissonance, I believed that YPI reduced harm toward young people of color in neighborhoods with pervasive police presence.

This monograph has four purposes:

(1) To explore and elevate an intervention, Youth Police Initiative, that works to bridge the tensions between police and the communities where they interact.

(2) To introduce a burgeoning theory of "knowing," which stems from the theories of Lewin, Bakal, and Blumer, and is one of the foundations of YPI.

(3) To address the dearth of literature about police attitudes, which have significant effect on officer decision-making.

(4) To highlight the lack of police training about how to work effectively with 16- to 25-year olds and offerYPI as a portal to more extensive communitypolicing strategies.

Salient themes that emerge from case studies in Boston and Brooklyn provide recommendations for further practice, policy, and research.

\section{Notes}

1 In the article by German Lopez, "Killings of police officers on duty are near record lows" he clarified that the Officer Down Memorial Page, which tracks officer deaths, estimated 129 police officers died in the line of duty in 2015, down 3\% from 2014. This continued the long-term downward trend, based on the organization's decades of statistics. The reduction in police deaths corresponds with the remarkable drop in crime. Violent crime rates in the US dropped by 49\% between 1994 and 2014, according to FBI data. Yet, there continues to be claims that law enforcement are under serious threat, potentially in an attempt to shift the conversation from heightened levels of police brutality. 
2 When I worked at the detention facility, I was struck by the similarities between PTSD experienced by soldiers from war and PTSD experienced by youth involved in turf wars in our cities. The motivations are quite similar: territory, resources, retaliation for wrongdoings. Research is beginning to corroborate this observation. Dr. Kerry Ressler the Principal Investigator in a study of 8,000 "gang"-involved youth in Atlanta showed that, "The rates of PTSD we see are as high or higher than Iraq, Afghanistan, or Vietnam veterans." Ressler said, "We have a whole population who is traumatized" (Beckett, 2014).

3 Cognitive dissonance is caused by conflicting attitudes, beliefs, or behaviors that produce mental discomfort that leads to an alteration to reduce the discomfort and restore balance. The concept is a method of the Normative Approach, part of the underlying framework of Youth Police Initiative, investigated here.

4 Name changed to protect identity. 


\section{Introduction}

News about police-involved shootings and other fraught exchanges with community members have widened awareness that police and community relations are in a volatile state. Some of the earliest principles of policing emphasized partnering with community members to ensure public safety (Stewart, Baumer, Brunson, \& Simons, 2009). The 1970s increased focus on community policing in response to police brutality during the Civil Rights movement. However, changes in policies and strategies, especially since $9 / 11$, suggest police-community relationships are weaker than ever. Positive relations between the police and communities they serve are vital in maintaining public safety. More research is needed to examine areas where practices could be improved to strengthen trust and confidence.

The Final Report of the President's Task Force on 21st Century Policing, published by the Obama Administration in May 2015 under the heading "Build and Strengthen Police-Community Relationships" (President's Task Force, 2015), made many recommendations for practices to promote police legitimacy. Under the current administration's decentralization of government policy with more political power and resources devolved to the states and municipalities, federal support has diminished. Thus, local governments have the distinct capacity to define policing policies and performance standards and can still implement this best-practice blueprint.

Several Task Force recommendations are consistent with the goals and practices of the Youth Police Initiative (YPI):

- Law enforcement agencies should proactively promote public trust by initiating positive non-enforcement activities to engage communities that typically have high rates of investigative and enforcement involvement with government agencies (14).

- Law enforcement agencies should create opportunities in schools and communities for positive non-enforcement interactions with police. Agencies should also publicize the beneficial outcomes and images of positive, trust-building partnerships and initiatives (15).

- Communities should adopt policies and programs that address the needs of children and youth most at risk for crime or violence and reduce 
aggressive law enforcement tactics that stigmatize youth and marginalize their participation in schools and communities (15).

The Case for Youth Police with Initiative provides a first-hand account of an intervention that supports these Task Force recommendations, through onthe-ground experiences of community members and police in Franklin Field Boston, MA and Brownsville, Brooklyn, NY, a neighborhood with one of the highest crime rates in New York City (Musumeci \& Parascandola, 2014).

Across the United States, police contact most often occurs with 16- to 25-year-olds (Hagan, Shedd, \& Payne, 2005; Hurst, Frank, \& Browning, 2000; Lieber, Nalla, \& Farnworth, 1998; Stoudt, Fine, \& Fox, 2011), but, with a few exceptions, there is a dearth of research on police attitudes toward youth (Marinos \& Innocente, 2008; Rabois \& Haaga, 2002; Thurman, Giacomazzi, \& Bogen, 1993). However, a substantive literature about youth attitudes toward police has emerged over the last decade (Carr, Napolitano, \& Keating, 2007; Meares, 2009; Stewart et al., 2009; Stoudt et al., 2011).

Police are a common presence in the lives of many youth, particularly in communities with high poverty rates (Berger, 2002; Buckley, Gann, Thurau, \& Wald, 2013; Watts \& Washington, 2014). Police are now routinely deployed in public schools and, with social and mental health services defunded, they are frequently the first responders in domestic disputes involving youth (Buckley et al., 2013). Despite the increasing challenges, officers receive surprisingly little training about adolescent psychology and behavior or useful strategies for youth engagement. As of 2013 , only $0.007 \%$ of overall police training was devoted to working with teenagers and young adults (Buckley et al., 2013).

\section{"Quality of Life" Laws and Decriminalization}

Interviews, focus groups, and field observations with young people, youth advocates, precinct police officers, and leaders relay how shifts in New York City criminal justice policies have affected relationships between teenagers and officers. In the 1970s, the city gave birth to the first wave of community policing, which culminated in the appointment of community policing advocate Commissioner Lee P. Brown by Mayor David Dinkins in 1989 (Brown, 2012). The pendulum swung back toward law and order in the 1990s in reaction to what was described as a "surge in violent crime by super predators,' but was in actuality a shift under the Clinton administration to "three strikes and you're out" laws, which made drug charges felonies and led to a sweeping "lock 'em up" attitude (Butts \& Travis, 2002).

"Broken Windows" policing, a metaphor referring to fixing broken windows in order to prevent further damage to the house, became a theory that to prevent crime one ostensibly had to address the context of crime (Howell, 2009). Initially, this belief lent itself to a preventive approach promoting "compassionate" police practices, including Crime Prevention through Environmental Design (CPTED). The CPTED approach postulates that if neighborhoods with high 
arrest rates are cleaned up by regular and thorough garbage collection, smashed windows in vacant buildings are sealed and boarded up, streetlights are fixed, and lights are installed in locations with persistent criminalized and criminal activities, criminal activity will decrease.

However, "Broken Windows" was not implemented holistically. Instead of partnering with municipal departments to address the actual environmental context or the needs of the individuals involved, the person "who broke the window" was simply put in jail. "Broken Windows" quickly devolved into a program of stopping smaller crimes to prevent larger ones, like DARE (Drug Abuse Resistance Education), which attempted to educate youth that drugs were bad and cigarettes and marijuana were gateway drugs. New York City police were trained to assess that jumping the turnstile, open containers of alcohol, violating curfew, playing dice/gambling outdoors, and assembling in large groups were all first steps to felonies.

The "Broken Windows" theory has now been largely discounted (Howell, 2009). What is true is that the significant increase in arrests driven by "Broken Windows" incurred the kind of collateral damage that destroyed thousands of families (Howell, 2009). This jump in arrests was compounded after 9/11, when the U.S. Patriot Act allowed law enforcement to stop and search without demonstrating just cause (NCLU, 2011, 2015; Rengifo \& Fratello, 2014; Ridgeway, 2007).Thus, "quality of life" crimes drove greater numbers of stops and searches that, in turn, led to further arrests and even more insidious damage (NCLU, 2011, 2015; Rengifo \& Fratello, 2014; Ridgeway, 2007). The impact of just one arrest can be tremendous: lost wages, lost jobs, school expulsion, the loss of a parent or caregiver, and breakup of families. Youth Police Initiative works to prevent that arrest from happening.

It is well documented that the attitudes of police toward the communities where they are deployed affect the quality of their interactions with residents (Sampson, 2012; Stewart et al. 2009). These attitudes are, in part, shaped by class, race, and neighborhood. It has also been shown that the lack of effective police training in how to communicate with community members is an important factor in citizen fatalities at the hands of police (Buckley et al., 2013). Examples of overt and implicit class and race bias, and resulting harms, are illustrated in this monograph as youth and police describe their experiences and interactions. Since police play such an integral role in the lives of youth, especially in low-income areas, one would expect that strategies to improve police attitudes toward teens would be at the top of the social science and urban policy research agenda, but serious gaps exist. This monograph attempts to fill that knowledge gap.

\section{Youth Police Initiative (YPI) in the Context of Other Youth and Police Programs}

Dr. Jim Isenberg, who developed Youth Police Initiative, stressed that supportive adults in the lives of youth are critical to their success: "The most important 
thing for any kid, forget any program you've ever heard of, is a positive adult role model. That has more influence on the kid than anything."'

Interventions with police officers and youth have traditionally focused on the "good" kids, who meet "Officer Friendly" in elementary school and later participate in Police Athletics League (PAL) and the Explorers program (Subhas \& Chandra, 2004). Evaluations of both PAL and Explorers have shown that preventive "Officer Friendly" interventions reinforce positive attitudes in youth that already have a positive perception of law enforcement (Anderson, Sabatelli, \& Trachtenberg, 2008; Subhas \& Chandra, 2004).

Youth Police Initiative (YPI) is unique because it does not recruit youth who already trust the police. The YPI's focus is youth living in communities with significant police presence, and brings teens, especially youth that are court involved, together with officers from their beat, two groups that are generally in conflict. Participants are most often court-involved youth or exposed to police contact on a regular basis.

The Youth Police Initiative model was based on Kurt Lewin's force field theory and the normative approach developed by Dr.Yitzhak Bakal, which are described in Chapter 1, as well as youth development theory and symbolic interactionism. Similar models focus on a shared vision and outcome, and cultural change through a cooperative group dynamic process. The youth development model ensures youth voices are central to the context of an intervention, akin to the principles of Lewin's action research.

An extensive literature review found only one youth police program comparable to YPI, reflecting to some extent the demographics of the youth, the Boston Teen Empowerment Police-Youth Reconciliation Project (PYRP) (EBSCO, 2019). There are many similarities and differences (Anderson et al., 2007; Fusoni, 2004). PYRP brought together police and youth from throughout the Roxbury and Dorchester neighborhoods, held police dialogue groups and used team-building exercises. However, it did not use a consistent structured curriculum. Activities and exercises were seemingly arbitrary, according to the facilitator.YPI is distinct from other youth-police programming because it has five structured facilitated sessions with youth and cops, with one youth-referred police officer present throughout the process. The first three sessions prepare the youth to train the larger police cohort in the last two sessions. In the case of PYRP, the evaluation data only came from one source, a post evaluation. The YPI has been evaluated with pre/post field-tested surveys, as well as pre/post qualitative interviews and field observation by three researchers, including observations from youth participants.

Findings from the PYRP evaluation were not consistent (Fischer, 2020). One officer reported that dialogues were disorganized and unclear, but another said that it was well organized and respectful. One officer said, "This program gave me the opportunity to interact with youth from the community I patrol. I realize that it is very important to deal with youth in a positive environment and not just see them as a negative radio call." Feedback from youth included: "Police and youth deal with a lot of similar issues that impact their 
relationships," "Police go through a lot and it may affect the way they interact with youth," and "I changed my misconceptions about police for the better." Thus, the PYRP findings corroborate what YPI has found, that police-youth interventions can have some positive effect, at least right after they take place, regardless of the structure.

While PYRP was a one-time effort within a larger neighborhood undertaking,YPI is practiced in many smaller jurisdictions, like public housing developments, with youth who have direct police contact, and police who interact most frequently on the ground with youth and have received multiple citizen complaints. Data from YPI sessions showed the most significant results occur when the training was carried out over time in localities such as Franklin Field, Boston, which was once called "Murder Corridor." The Franklin Field case study is described in Chapter 3 by on-the-ground players from the public housing development.

\section{Case Study}

The setting for this monograph's case study, along with Franklin Field, Boston, was the Brownsville neighborhood in the borough of Brooklyn, New York, which was experiencing the highest rate of public violence, and the third highest rate of reported police misconduct cases in New York City (CCRB, 2014). Brownsville was a newly introduced site for YPI and served as a case study because it demonstrated the effects of YPI after one training round, in comparison to 13 years in Boston. A commentator noted, "It's official: Brownsville is the murder capital of New York," with more shootings than anywhere else in the city (Musumeci \& Parascandola, 2014). Moreover, New York City Civilian Complaint Review Board (2014) annual statistics showed that the majority of complaints against police that year were from African Americans (55\%) in Brooklyn (33\%) in comparison to other New York City boroughs. There were 81 complaints from the 73rd Precinct, which is Brownsville, the third highest number in the city.

\section{Case Study Methodology}

A phenomenological approach is well suited for an in-depth case study that illustrates specific phenomena through the perceptions of the actors in a place or situation, as told by the actual people living in or occupying that space, to better explain what occurs there (Husserl, 1970). The approach is powerful for understanding personal experience, while gaining insights into motivations and actions (Husserl, 1970). The methods are especially effective at revealing whether normalized practices are problematic or beneficial. Thus, this research method can inform, support, or challenge policies and actions related to community-police relations (Husserl, 1970).

Methods for evaluating YPI outcomes were primarily phenomenological. Embedded information and perceptions were collected through qualitative 
methods: focus groups, interviews (with informed consent and Institutional Review Board approval), and field notes, reflecting the perspective and experience of the participants. Findings from current and retrospective surveys were woven in as part of the exploration. Youth, police, law enforcement leadership, and community leaders were interviewed pre- and post-YPI. Focus groups were led with separate groups of youth and police. The youth participants and two researchers trained in ethnographic methods observed all YPI sessions. Detailed ethnographic field notes were taken by all youth and researchers without collaboration with each other. This was a test of inter-rater reliability, ${ }^{1}$ a comparison of field notes post write-up, to analyze and reflect upon significant differences and similarities in observations and interpretations. The data analysis method, thematic coding, is described in Chapter 7.

\section{Action Research}

Social psychologist Kurt Lewin's (1890-1947) theoretical framework is the foundation of the Youth Police Initiative methodology (Kelley, 1991), including his force field group dynamic theory and his supporting concept of interdependent fates. Youth participating in the YPI sessions executed Kurt Lewin's method of action research.

Kurt Lewin's action research approach was introduced during the 1940s (Kelley, 1991). His approach underscores the power relationship between the researcher and those researched (Kelley, 1991). Action research involves participants from the community with researchers in pursuit of a simultaneous process of action and evaluation. Research participants study the effects of their own actions, identifying biases, and work to transform relationships within their community or organization, in a cyclical process of planning, action, and data collection. Different variations of action research have evolved since Lewin's day and its validity as a scientific research method is sometimes questioned. Its strengths, however, in providing groups or communities a self-evaluative, collaborative, and decision-making role are widely accepted (Kelley, 1991).

This author field-tested the interview guide with the youth to receive feedback about the legitimacy of the questions to yield the most viable data. She provided training so youth could conduct ethnographic field notes, to understand youth perspective of YPI. Observations from the researchers were also included. Interviews were conducted with participating youth and police officers, as well as with CBO leaders, and police administrators. Indepth interviews and focus groups were conducted twice, before and right afterYPI.

\section{Chapter Contents}

Chapter 1 describes the theoretical framework of Youth Police Initiative: Kurt Lewin's force field theory and Dr.Yitzhak Bakal's Normative Approach. 
Chapter 2 is an introduction to the Youth Police Initiative, its history, and how it works, as described by the YPI founder and directors.

Chapter 3 is an extensive case study of how YPI worked in Franklin Field, Boston over a 13-year period, through interviews with a youth, youth advocate, program director and a police lieutenant.

Chapter 4 examines Brownsville, Brooklyn youth and community organization leaders' perceptions of police and police precinct commander and officers' perceptions of youth before YPI.

Chapter 5 is an in-depth description of actual YPI sessions. What transpired between youth and police in Brownsville, Brooklyn?

Chapter 6 chronicles the youth and police responses post-YPI.

Chapter 7 summarizes and analyzes the themes that emerged from YPI revealing challenges between police and young people in Boston and Brownsville.

Chapter 8 summarizes and analyzes the themes that emerged from YPI revealing positive outcomes from the experiences of YPI in Boston and Brownsville. Both chapters invite the reader into the literature that illuminates the themes from the narratives and shows gaps in research.

Chapter 9 relates the themes to recommendations for research, policy, and practice, offering a guidebook to policy-makers, practitioners, and researchers. Chapters 2 through 6 contain first-person narratives by interlocutors describing their YPI experience. True to the phenomenological approach, the first-person narrative is meant to be an immersive, vicarious experience, allowing the reader to see through the eyes of the YPI developers and participants.

\section{Note}

1 Inter-rater reliability can be used for field observations. It refers to the degree to which different raters give consistent estimates of the same behavior. 
of YPI not only builds trust between community members and police officers, but also opens residents up to other useful social services, "To create a sense of community, you need a place, you need activities, you need YPI, definitely, to change perception in culture." Chapter 2 details how the YPI training works, as described by the founder and directors.

\section{Notes}

1 The purpose of systems theory is to develop unifying principles through the integration of various disciplines from multiple perspectives to comprehend a system (Bertalanffy, 1968). Systems are goal oriented and engage in feedback with the environment in order to meet their aims. Every part of the system is interdependent, working together toward the goals. Productive dynamic systems are self-organizing, adaptive to the changes in the environment.

2 Continuum of care is a concept involving an integrated system of care that supports people over time through a comprehensive array of services spanning all levels of intensity of care (Evashwick, 1989).

3 Kolb's experiential learning cycle (Kolb, 1984), draws from Dewey's educational philosophy, Piaget's developmental psychology, and Lewin's social psychology. Kolb's (1984) four-stage model describes the process of learning that assimilates information through experience. Learning begins when one is immersed within an experience. Stage 1 of the model-reflective observation; Stage 2-reflective observation, or examination, leads to an explanation about the concrete experience; which represents the third stage of the model, abstract conceptualization. Stage 3 includes processing and reflection of the consequences that resulted from the initial action(s). Stage 4 is active experimentation when the individual applies the model of explanation when presented with a new situation or experience (Burke \& Bush, 2013). Pragmatist Dewey (1916) professed that the fundamental principle of education as a dynamic process is too often contradicted within our teaching methodologies, and emphasized the importance of individuals interacting with their environment. 
white officers more negative assumptions and judgments. However, this was not the case for every respondent. Affirmative views of the community and youth linked to more positive interactions. The consistent theme was that no matter their race, gender, where they were from, years on the force, or age, responses illustrated that negative perceptions of Brownsville and its residents were connected to more negative interactions.

"Environmental Conditions Criminalize Behaviors" and "New Laws: Pendulum Swings to Community Policing" also appeared in the pre-YPI youth perceptions. Police noted the overpowering relationship between environmental factors and criminalized behaviors and generally thought the change in qualityof-life laws would improve community relations. Police also mentioned that they looked forward to YPI because a prevalent belief was that "Positive Activities Between Youth and Police Improve Relations."

The pre-YPI perceptions youth and police had of each other were enacted and challenged when they came together. The most salient themes are synthesized, analyzed, and connected to outcomes and recommendations in Chapters 7,8 , and 9 .

\section{Notes}

1 Fights.

2 Diversion, also called alternative to incarceration, is a court-mandated intervention used instead of detention to prevent the collateral damage it causes to individuals, families, and communities. Diversion programs can include but are not exclusive to educational, vocational, substance use, and mental health services. Probation officers and case managers are assigned to diversion cases to ensure compliance with a case plan. If participants do not comply with a court order, detention is a consequence. This is a critique of diversion. Youth in the juvenile justice system are disproportionately affected by the lack of school and housing supports that are often the real drivers behind criminalized behaviors. Most of the probation violations and subsequent detentions are because of "running away" from a home placement and/ or truancy.

3 Discipline and Punish is a history of the modern penal system. Foucault analyzed punishment in its social context and examined how changing power relations affected punishment. This applied to Dahlia's perspective of police in Brownsville. She asserted that especially black teens are targeted for punishment disproportionately because of institutionalized racism and classism.

4 Walter was referring to the fatal shooting of Akai Gurley by the rookie officer Peter Liang in November 2014 (Carrega-Woodby, McLaughlin and Gregorian, 2016).

5 New York City Police Department's data management system was created in 1994. Police leadership from all the boroughs travel on a rotating schedule to One Police Plaza weekly to report in granular detail about crime trends and the strategies to address them. The NYPD brass map and analyze crime throughout the city and allocate resources according to the concentration of activity. The three-hour sessions are intensive and demanding, holding precinct captains responsible for application of resources in relationship to reductions in criminal activity (Smith, 2018). 
6 Park Slope is a Brooklyn neighborhood known for significant change in demographics and a reduction in violent crime and arrests after extensive gentrification. Research showed that the process of gentrification can actually show a spike in crime (Aikman, 2014; Atkinson, 2002; Covington \& Taylor, 1989; Fayyad, 2017). The topic is controversial and findings are mixed.

7 The literature is actually mixed on the outcomes (Desmond, Papachristos \& Kirk, 2016; Diedrich \& Luthern, 2016).

8 Neighborhood Community Officers, further explicated in Chapter 7.

9 City University of New York John Jay College of Criminal Justice

10 There is nothing in the current literature about CRAFT (January 8, 2020). There is a new tool in NYC called Elucd pronounced "e-loo-cid," as in "elucidate." It is meant to help residents get more comfortable dealing with police, by assessing citizens' perceptions of police interactions and ostensibly using this response to measure police performance (Weichselbaum, 2018). There are no studies yet that show the outcomes of Elucd.

11 New York State's Operation IMPACT (Integrated Municipal Police Anti-Crime Teams) was developed in 2004. The initiative has a strong emphasis on relationships between law enforcement agencies, crime analysis, intelligence development, and information sharing to assist in the reduction of firearm-related homicides and shootings (DCJS, 2013). The jurisdictions that account for the highest volume of violent crime within each county are the focus of the IMPACT crime reduction efforts (DCJS, 2013). Critique of Operation IMPACT since its implementation was that it caused inexperienced rookie officers to be sent to some of the city's highestcrime precincts. They were charged to do enforcement with relatively little discretion. While there was no overt policy of "zero tolerance," arrests, summonses, and stops spiked by more than 40\% from 2003 to 2011, with diminishing crime reduction returns and increased alienation of many citizens. By 2011, the NYPD had recorded 694,482 reasonable-suspicion stops, many conducted by officers assigned to Operation IMPACT. Directing the least experienced officers to aggressively employ reasonable suspicion had deleterious effects on communities (Bratton, 2016). 
at a poorly attended meeting where vendors were being treated punitively for speaking out against receiving tickets. Even community leaders that partner with the police to make this initiative work said the meetings were poorly attended (Abraham \& Mercado, 2018). Even so, in YPI sessions, OfficerVasquez emphasized the importance of youth attending the NCO meetings.

\section{Brownsville Is Exploited as a Testing Ground for New Initiatives}

Dahlia ended her interview expressing her frustration with new programs because so many social service providers used Brownsville as a testing ground for new initiatives. "Many things come into the community and then leave ... because Brownsville is consistently number one in juvenile arrests, infant mortality, diabetes, and other areas. They pilot programs, but there is no long-term investment." Although she was wary of YPI too, Dahlia was open to participating if it would actually improve what she described as the intractably abusive and traumatic dynamic between the criminal justice system and Brownsville young people. Dahlia claimed that it was the criminalization of the environment and the neighborhood that caused the young people to be abused by law enforcement. This concept is further explored in Chapter 8.

\section{Conclusion}

Themes related to challenges that emerged from the data collection before and during YPI were identified from interviews and focus groups, as well as field notes in Brooklyn, and interviews and site visits in Boston. They included: the community is a police state; generational transmission of trauma from encounters with police; profiling and persistent harassment; officer identity; the community is plagued by violence; rookie cops are the shooters; the system is set up to fail us; what are police trained to do and why; and dehumanizing conditions of confinement. Chapter 8 is an analysis of themes that show how YPI was related to positive changes between youth and police, addressing some of the concerns reflected above.

\section{Note}

1 Frank Jude Jr. suffered a brutal beating in Milwaukee's Bay View neighborhood October 2005. His attorney reported,"He was kicked repeatedly in the head, stripped naked, and threatened with a knife," by over a dozen officers. Authorities knew who was involved, but more than three months later no one was charged or even arrested. Off-duty Milwaukee police officers claimed Jude stole one of their badges and said they had to subdue Jude because he was aggressive. Witnesses reported that Jude did not steal anything, wasn't resisting, and that an officer dragged him out of a truck and beat him maliciously. Jude was arrested, taken by police wagon to the hospitalno ambulance was called. Prosecutors did not file charges against him. They focused 
on the off-duty officers' actions. The beating led to the largest number of firings in department history, federal convictions of seven officers, and a series of reforms.

For the full story go to: www.jsonline.com/story/news/investigations/2016/09/29/ archive-police-suspected-frank-judes-beating/91253086/ 
Youth and police both agreed that the training was useful. Each participant was surprised that they were able to have open and honest communication. Young people and officers believed that YPI would change future interactions on the streets. However, any sustainable changes will only be measured over time.

\section{Conclusion}

Themes identified from Live and post-YPI data collection connected to a transformative effect. YPI opens the door to addressing environmental conditions, being a point of entry into community policing, hiring police from the neighborhood, alleviating tensions between warring housing developments, involving parents and community members, promoting youth as leaders, providing prevention and after care, and feeding an overall improvement in police-youth relations. Concrete recommendations related to these themes are outlined in Chapter 9.

\section{Note}

1 The Department of Labor defined "Unemployment" and "Underemployment" in order to determine how to allocate benefits and services. Unemployment means that you were previously gainfully working but are currently not formally employed. Underemployed signifies that your job does not provide a living wage, or baseline quality of life. 
"knowing." Central to his method is that the voice of the people experiencing phenomena drives the narrative. An insider perspective ofYPI through youth and police narratives exemplified how communities can heal from and prevent the trauma experienced from generations of containment policing.

This exploration found that YPI humanized the relationship between youth and police even after one training and had enduring effects after thirteen years. Lieutenant Torigian who worked in Franklin Field Boston said YPI was a success because young people's "dreams were safe with us." Darryl Knight, also from Franklin Field Boston, who hated police because they took him away from his mother at five years old, said now that because ofYPI, "My dreams are limitless." Limitless dreams are a foundation of the United States, are they not?

\section{Note}

1 Blumer stated that symbolic interactionism rests on three premises:

(1) Human beings act toward things on the basis of the meanings of things have for them;

(2) the meaning of such things derives from the social interaction we have with each other; and

(3) these meanings are handled in, and modified through experience and over time (Blumer, 1969). 


\section{References}

Abraham, R., \& Mercado, A. (2018). NYPD's neighborhood policing meetings aren't reaching intended audience. City Limits, April 24.

ACLU. (2011). Banking on bondage: Private prisons and mass incarceration. www.aclu. org/banking-bondage-private-prisons-and-mass-incarceration.

Aikman, M. D. (2014). Gentrification's effect on crime. https://sites.duke.edu/ urbaneconomics/fi/?paged $=4$.

Algar, S., \& Saul, J. (2015). NYPD set arrest quotas for minority cops in their own Communities. N.Y. Post. https://nypost.com/2015/09/01/cop-suing-over-minorityarrest-quotas-says-he-faced-retaliation/ [https://perma.cc/XFB3-8AES], retrieved June 14, 2019

Alpert, G. P., \& Dunham, R. G. (1997). The force factor: Measuring and assessing police use of force and suspect resistance. Washington, DC: Police Executive Research Forum.

Alpert, G., Flynn, D., \& Piquero, A. (2001). Effective community policing performance measures justice research and policy. Justice Research and Policy, 3(2), 79-94.

Anderson, S.A., Sabatelli, R.M., \& Trachtenberg,J. (2007). Community police and youth programs as a context for positive youth development. Police Quarterly, 10, 23-40.

Anderson, S. A., Sabatelli, R. M., \& Trachtenberg, J. (2008). A process and outcome evaluation of police working with youth programs. Journal of Youth Development, 3(2).

Andresen, M. A. (2012). Unemployment and crime: A neighborhood level panel data approach. Social Science Research, 41, 1615-1628, http://dx.doi.org/10.1016/ j.ssresearch.

Ariel, B., Farrar, W., \& Sutherland, A. (2014). The effect of police body-worn cameras on use of force and citizens' complaints against the police: a randomized controlled trial. Journal of Quantitative Criminology, 31, 509-535. https://doi.org/10.1007/ s10940-014-9236-3.

Arthur, H., Bowler, S., \& Fischer, N. R. (2011). Children, youth and families. In S. A. Estrine, R. T. Hettenbach, H. Arthur \& M. Messina (Eds.), New directions in behavioral health: Service delivery strategies for vulnerable populations, (pp. 71-85). New York: Springer Publishing.

Atkinson, R. (2002). Does gentrification help or harm urban neighborhoods? an assessment of the evidence-base in the context of the new urban agenda. ESRC Centre for Neighborhood Research. 
Aymer, S. R. (2016). I can't breathe:A case studying-helping Black men cope with racerelated trauma stemming from police killing and brutality. Journal of Human Behavior in the Social Environment, 26(3-4), 367-376.

Balkin, J. (1988). Why policemen don't like policewomen. Journal of Police Science and Administration, 16, 29-38.

Bateson, K., McManus, M., \& Johnson, G. (2019). Understanding the use, and misuse, of Adverse Childhood Experiences (ACEs) in trauma-informed policing. The Police Journal. https://doi.org/10.1177/0032258X19841409.

Beckett, L. (2014). Living in a violent neighborhood is as likely to give you PTSD as going to war yet this at-home PTSD crisis remains largely ignored. Mother Jones, February 4.

Belknap, J., \& Shelley, J. K. (1993). The new lone ranger: Policewomen on patrol. American Journal of Police, 12, 47-75.

Bellamy, L. (2019).Violent crime drops significantly in City of Newburgh. Time Herald Record, www.recordonline.com/news/20190509/violent-crime-drops-significantly-incity-of-newburgh, Retrieved January 4, 2020.

Bellis, M. A., Phillips-Howard, P. A., Hughes, K., Hughes, S., Cook, P. A., Morleo, M. Hannon, K., Smallthwaite, L., \& Jones, L. (2009). Teenage drinking, alcohol availability and pricing: a cross-sectional study of risk and protective factors for alcoholrelated harms in school children. BioMedCenter Public Health, 9: 380.

Berger, R. R. (2002). Expansion of police power in public schools and the vanishing rights of students. Social Justice, 29: 119-130.

Bertalanffy, L.V. (1968). General Systems Theory. New York: Braziller.

Blumer, H. 1969. Symbolic interactionism: Perspective and method. Englewood Cliffs, NJ: Prentice-Hall.

Bolton, K. Jr., \& Feagin, J. R. (2004). Black in blue: African-American police officers and racism. New York, NY: Routledge.

Boston Housing Authority. (2020). www.bostonhousing.org/en/HousingDevelopmentDetail. aspx?hid=112, retrieved January 4, 2020.

Bouie, J. (2014). Black and blue: Why more diverse police departments won't put an end to police misconduct. Slate. www.slate.com/articles/news_and_politics/ politics/2014/10/diversity_won_t_solve_police_misconduct_black_cops_don_t_ reduce_violence.html, retrieved June 14, 2019.

Brandl, S. G., Stroshine, M. S., \& Frank, J. (2001). Who are the complaint-prone officers? An examination of the relationship between police officers' attributes, arrest activity, assignment, and citizens' complaints about excessive force. Journal of Criminal Justice, 29, 521-529.

Bratton, W. (2016). Precision policing: A strategy for the challenges of 21st century law enforcement. Retrieved from www.manhattan-institute.org/html/urban-policy2018-precision-policing-strategy-21st-century-law-enforcement-11508.html, January 20, 2020.

Bronfenbrenner, U. (1979). The ecology of human development: Experiments by nature and design. Cambridge, MA: Harvard University Press.

Brown, L. (2012). Policing in the 21st century: Community policing. Bloomington, IN: Author House.

Bryant-Davis, T., Adams, T., Alejandre,A., \& Gray,A.A. (2017). The trauma lens of police violence against racial and ethnic minorities. Journal of Social Issues, 73(4), 852-871. 
Burnes, B. (2004). Kurt Lewin and the planned approach to change: A re-appraisal. Journal of Management Studies, https://doi.org/10.1111/j.1467-6486.2004.00463.x.

Comas-Díaz, L. \& Bryant-Davis, T. (2016). Womanist and Mujerista Psychologies: Voices of Fire, Acts of Courage. Washington DC: American Psychological Association.

Buckley, P. P., Gann, G., Thurau, L. H., \& Wald, J. (2013). If not now, when? A survey of juvenile justice training in America's police academies. Cambridge, MA: Strategies for Youth (SFY).

Burke, A. S., \& Bush, M.D. (2013). Service learning and criminal justice: an exploratory study of student perceptions. Educational Review, 65(1), 56-69, http://dx.doi.org/10. 1080/00131911.2011.638138.

Butts J., \& Travis, J. (2002). The rise and fall of American youth violence: 1980 to 2000. Research for safer communities. Urban Institute Report.

Cantor, D., \& Land, K. C. (1985). Unemployment and crime rates in the post-World War II United States. American Sociological Review, 50, 317-332.

Carbado, D. W., \& Richardson, L. S. (2018). The black police: policing our own locking up our own: crime and punishment in black America. Harvard Law Review, May 10.

Carr, P. J., Napolitano, L., \& Keating, J. (2007). We never call the cops and here is why: A qualitative examination of legal cynicism in three Philadelphia neighborhoods, Criminology, 45(2).

Carrega-Woodby, C., McLaughlin, A. \& Former, D. G. (2016). NYPD cop Peter Liang spared jail time in fatal shooting of Akai Gurley at Brooklyn housing project. New York Daily News, April 19.

Center on Juvenile and Criminal Justice (2007).www.cjcj.org/uploads/cjcj/documents/ Juvenile_DetentionSF.pdf, retrieved June 14, 2019.

Centre for Policing Equity (2019). https://policingequity.org/

klinranCCRB (Centre for Restorative Justice) (2009). Effectiveness of restorative justice implementation in South Australian Schools. Centre for Restorative Justice: Adelaide.

Child Witness to Violence Project (2013). www.childwitnesstoviolence.org/.

Child Welfare Information Gateway (2013). www.childwelfare.gov/.

Civilian Complaint Review Board. (2014). Annual Report, XXII (2).

City Data. (2019). www.city-data.com/neighborhood/Franklin-Field-South-BostonMA.html, retrieved December 19, 2019.

Clifasefi, S. L., Lonczak, H. S., \& Collins, S. E. (2017) Seattle's Law Enforcement Assisted Diversion (LEAD) program: Within-subjects changes on housing, employment, and income/ benefits outcomes and associations with recidivism Crime \& Delinquency, 63(4): 429-445.

Cohen, S., \& Rae, L. (2002). Wraparound plan delivers success at less cost. Journal News, December 15.

Collins, P. (2015). Intersectionality's definitional dilemmas. Annual Review of Sociology, 41: $1-20$.

Connell, R.W., \& Messerschmidt, J.W. (2005). Hegemonic masculinity: Rethinking the concept. Gender and Society, 19(6): 829-859. JSTOR 27640853.

Cooper, H., Moore, L., Gruskin, S., \& Krieger, N. (2004). Characterizing perceived police violence: implications for public health. American Journal of Public Health, 94(7), 1109-1118. 
Correlll, J., Hudon, S. M., Guillermo, S., \& Ma, D. S. (2014). The police officer's dilemma: a decade of research on racial bias in the decision to shoot. Social \& Personality Psychology, 8, 201-210.

Corsianos, M. (2009). Policing and gendered justice: Examining the possibilities. Toronto, Canada: University of Toronto Press.

Covington, J., \& Taylor, R. B. (1989). Gentrification and crime robbery and larceny changes in appreciating Baltimore neighborhoods during the 1970s. Urban Affairs Review, 25(1): 142-172.

Crenshaw, K.W. (1994). Mapping the margins. In M. A. Fineman \& R. Mykitiuk (Eds.), The public nature of private violence. New York: Routledge.

Crotty, S. N., Crotty J. N., \& Fernandez, S. (2017). Will more black cops matter? Officer race and police-involved homicides of black citizens. Public Administration Review, 77(2), 206-216. DOI: 10.1111/puar.12734.

Cushing, C., Jensen, C. D., Miller, M. B., \& Leffingwell. (2014). Meta-analysis of motivational interviewing for adolescent health behavior: efficacy beyond substance use. Journal of Counseling and Clinical Psychology, 82(6), 1212-1218.

D’Amico, E. J., Hunter, S. B., Miles, J. N.V, Ewing, B. A., \& Osilla, K. C. (2013). A randomized controlled trial of a group motivational interviewing intervention for adolescents with a first time alcohol or drug offense. Journal of Substance Abuse Treatment, 45(5) https://doi.org/10.1016/j.jsat.2013.06.005.

D'Amico, E. J., Osilla, K. C., \& Hunter, S. B. (2010). Developing a group motivational interviewing intervention for first-time adolescent offenders at-risk for an alcohol or drug use disorder. Alcoholism Treatment Quarterly, 28(4), 417-436. https://doi.org/10. 1080/07347324.2010.511076.

Davis, A. (2000). Masked racism: Reflections on the prison industrial complex. Indigenous Law Bulletin, 4 (27).

DeJong, C. (2004). Gender differences in officer attitude and behavior: Providing comfort to citizens. Women \& Criminal Justice, 15, 1-32.

Department of Justice. (2011). Investigation of the New Orleans Police Department. United States Department of Justice Civil Rights Division, https://www.justice.gov/ sites/default/files/crt/legacy/2011/03/17/nopd_report.pdf.

Desmond, M., Papachristos, A. V., \& Kirk, D. S. (2016). Police violence and citizen crime reporting in the black community. American Sociological Review, https:// doi.org/10.1177/0003122416663494.

Dewey, J. (1916). Democracy in education: An introduction to the philosophy of education. New York: The Free Press.

Diedrich, D., \& Luthern, A. (2016). 911 calls fell in black Milwaukee neighborhoods after Jude beating, study finds. Milwaukee Journal Sentinel, www.jsonline.com/story/ news/investigations/2016/09/29/911-calls-fell-black-milwaukee-neighborhoodsafter-jude-beating-study-finds/90907882/, retrieved June 14, 2019.

Division of Criminal Justice Services. (2013). www.criminaljustice.ny.gov/crimnet/ ojsa/impact/2013annualreport.pdf.

Donner, C. M., Maskaly,J., Kanani, N., \& Thompson,A. (2018). Self-control and the police code of silence: Examining the unwillingness to report fellow officers' misbehavior among a multi-agency sample of police recruits. Journal of Criminal Justice, 56, 11-19. 
EBSCO (2019). Database. http://search.ebscohost.com/login.aspx?direct $=$ true $\& d b=a$ $9 \mathrm{~h} \&$ bquery $=$ police + attitudes + towards + youth $\&$ type $=1 \&$ searchMode $=$ Standard $\&$ sit $\mathrm{e}=$ ehost-live

Eck, J. E., \& Spelman, W. (1987). Problem-solving: Problem-oriented policing in Newport News. Police Executive Research Forum (PERF) United States of America, National Institute of Justice (NIJ), www.ncjrs.gov/App/Publications/ abstract.aspx?ID=111964.

Evashwick, C. (1989). Creating the continuum of care. Health Matrix, 7(1), 30-39.

Fayyad, A. (2017). The criminalization of gentrifying neighborhoods. The Atlantic, December 20.

Feldstein, S., \& Ginsburg, J. (2006). motivational interviewing with dually diagnosed adolescents in juvenile justice settings. Brief Treatment and Crisis Intervention, 6(3) DOI: 10.1093/brief-treatment/mhl003.

Fifield, J. (2016). Does diversifying police forces reduce tensions? Pew Trusts. www. pewtrusts.org/en/research-and-analysis/blogs/stateline/2016/08/22/does-diversifying-police-forces-reduce-tensions, retrieved June 14, 2019.

Finkelhor, D., Turner, H., Ormrod, R., Hamby, S., \& Kracke, K. (2009). Children's exposure to violence: A comprehensive national survey, https://www.ncjrs.gov/pdffiles1/ ojjdp/227744.pdf.

Fischer, N. R. (2011). Model approaches for children and youth with serious emotional disturbance: Systems of care and wraparound. In S. A. Estrine, R.T. Hettenbach, H. Arthur, \& M. Messina (Eds.), New directions in behavioral health: Service delivery strategies for vulnerable populations (pp. 87-104). New York: Springer Publishing.

Fischer, N. R. (2020). Interdependent fates: Youth and police-can they make peace? Peace and Conflict: Journal of Peace Psychology, 2(999), 1-5.

Fisher-Stewart, G. (2007). Community policing explained: A guide for local governments. Washington, DC: U.S. Department of Justice, Office of Community Oriented Policing Services.

Fitzpatrick, J. (2015). National Orlando police complaints in the spotlight as African American ex-chief runs for congress. The Atlantic, September 8.

Forman, B. (2016). The geography of incarceration: The cost and consequences of high incarceration rates in vulnerable city neighborhoods. A special report from the Boston Indicators Project in Partnership with MassINC and the Massachusetts Criminal Justice Reform Coalition.

Foucault, M. (1977). Discipline and punish:The birth of the prison, New York: Random House. Forrest, C. B., Tambor, E., Riley, A. W., Ensminger, M. E., \& Starfield, B. (2000). The health profile of incarcerated male youths. Pediatrics, 105(2), 286-291.

Freudenberg N. (2001). Jails, prisons, and the health of urban populations: a review of the impact of the correctional system on community health. Journal of Urban Health, 78(2), 214-235.

Freire, P. (1972). Pedagogy of the oppressed. New York: Herder \& Herder.

Fulcher, P. A. (2012). Hustle and flow: Prison privatization fueling the prison industrial complex. Washburn Law Journal, 51, 589-617.

Fuller, C. \& Goodman, H. (2019). The answer is in the community: Credible messengers and justice system involved youth. Social Work with Groups: A Journal of Community and Clinical Practice. 
Fusoni, M. (2004). Teen empowerment: Youth, police, and neighbors in partnership. New Directions for Youth Development, 106, 61-71.

Gardner, T.G. (2009). Black-on-black policing: Ethnic identification among African American police in Washington, DC and Oakland, CA. https://sociology.berkeley.edu/ sites/default/files/documents/student_papers/Gardner_Clark_BNBPolicing.pdf.

Garland, A. F., Lau, A. S., Yeh, M., McCabe, K. M., Hough, R. L., \& Landsverk, J. A. (2005). Racial and ethnic differences in utilization of mental health services among high-risk youths. American Journal of Psychiatry, 162(7), 1336-1343.

Geller, A., Fagan, J., Tyler, T., \& Link, B. G. (2014). Aggressive policing and the mental health of young suburban men. American Journal of Public Health, 104(12), 2321-2327.

George, A. (2018). www.smithsonianmag.com/smithsonian-institution/1968-kernercommission-got-it-right-nobody-listened-180968318/\#i3ve7WhppYsBvyAB.99. Retrieved December 10, 2019.

Gillon, S. M. (2018). Separate and unequal: The Kerner Commission and the unraveling of American Liberalism. New York: Basic Books.

Goetz, E. G. (2013a). New deal ruins: Race, economic justice and public housing policy. Ithaca, NY: Cornell University Press.

Goetz, E. G. (2013b). Too good to be true? The variable and contingent benefits of displacement and relocation among low-income public housing residents. Housing Studies, 28, 235-252. DOI:10.1080/02673037.2013.767884.

Goff,P.A.,Eberhardt,J.L.,Williams, M.J., \& Jackson,M.C.(2008). Not yet human:Implicit knowledge, historical dehumanization, and contemporary consequences. Journal of Personality and Social Psychology, 94(2), 292-306. DOI: 10.1037/0022-3514.94.2.292.

Goldstein, H. (1987). Toward community-oriented policing: potential, basic requirements, and threshold questions. Crime and Delinquency, 33(1), 6-30.

Grennan, S. A. (1987). Findings on the role of officer gender in violent encounters with citizens. Journal of Police Science and Administration, 15, 78-85.

Haberman, C. (2018). For Private Prisons, Detaining Immigrants Is Big Business. New York Times.

Hagan, J., Shedd, C., \& Payne, M. (2005). Race, ethnicity, and youth perception of criminal injustice. American Sociological Review, 7, 381-407.

Harmon, R. (2016). Federal programs and the real costs of policing. New York University Law Review, 90, 870-960.

Harnett Associates (2006). Crime fighting in Oakland:An assessment of the Oakland police department. December 28. www.oaklandnet.com/documents/CrimeFightingHarnett Report12206.pdf.

Henry, T. K. S., \& Franklin, T.W. (2019). Police legitimacy in the context of street stops: the effects of race, class, and procedural justice. Criminal Justice Policy Review, 30(3), 406-427.

Hickman, M. J., Piquero, A. R., Lawton, B. A., \& Greene, J. R. (2001). Applying Tittle's control balance theory to police deviance. Policing, 24(4), 497-520.

Hinds, L. (2009). Youth, police legitimacy and informal contact. Journal of Police and Criminal Psychology, 24, 10-21.

Hodges, B. (2019). 4 ways officers can improve neighborhood relationships. www. policeone.com/community-policing/articles/482665006-4-ways-officers-canimprove-neighborhood-relationships/ Retrieved June 8, 2019. 
Homant, R. J., \& Kennedy, D. B. (1985). Police perceptions of spouse abuse: A comparison of male and female officers. Journal of Criminal Justice, 13, 29-47.

Howell, K. B. (2009). Broken lives from broken windows: The hidden costs of aggressive order-maintenance policing. New York University Review of Law and Social Change, 33 , 271-329.

Hrach, T.J. (2016). The riot report and the news: How the Kerner Commission changed media coverage of black America. Amherst, MA: University of Massachusetts Press.

Hughes, K., Quigg, Z., Eckley, L., Bellis, M., Jones, L., Calafat, A., Kosir, M., \& van Hasselt, N. (2011). Environmental factors in drinking venues and alcohol-related harm: the evidence base for European intervention, Addiction, 1, 37-46.

Hurst,Y., Frank, J., \& Browning, S. (2000). The attitudes of juveniles toward the police. Policing An International Journal of Police Strategy and Management, 23, 37-53.

Husserl, E. (1970). The crisis of European sciences and transcendental phenomenology: an introduction to phenomenological philosophy. Evanston, IL: Northwestern University Press.

Hyanghee, L., Heafnera, J., Sabatellia, R. M. \& LaMotteb, V. (2017). Side-by-side: An evaluation of Connecticut's police and youth interaction model. Journal of Human Behavior in the Social Environment, 27(8), 806-816 https://doi.org/10.1080/109113 59.2017.1339652.

In the Public Interest. (2013). Criminal: How lockup quotas and "low-crime taxes" guarantee profits for private prison corporations. Retrieved from www.inthepublicinterest.org/ criminal-how-lockup-quotas-and-low-crime-taxes-guarantee-profits-for-privateprison-corporations/ October 1, 2019.

Ivkovic, S. K. (2005). Police (mis) behavior: A cross-cultural study of corruption seriousness. Policing: An International Journal of Police Strategies \& Management, 28(3), 546-566.

James, N. (2018). Recent violent crime trends in the United States. Congressional Research Services, June 20.

Justice Policy Institute. (2011). Gaming the system: How the political strategies of private prison companies promote ineffective incarceration policies. Washington, DC: Justice Policy Institute, June 22.

Kelley, H. H. (1991). Lewin, situations, and interdependence, Journal of Social Issues, 47(2), 211-233.

Kessler R. C., Mickelson K. D., \& Williams D. R. (1999). The prevalence, distribution, and mental health correlates of perceived discrimination in the United States. Journal of Health Social Behavior, 40(3), 208-230.

Khaleeli, H. (2016). \#SayHerName: Why Kimberlé Crenshaw is fighting for forgotten women. The Guardian, May 30.

King, S. (2016). Why we must require cops to live in or near the area they police. New York Daily News, July 29.

Kirby, H., Libal, B., Madison, P., Morris, J., \& Quong Charles, K. (2013). The dirty thirty: Nothing to celebrate about 30 years of Corrections Corporation of America. https:// grassrootsleadership.org/sites/default/files/uploads/GRL_Dirty_Thirty_formatted_ for_web.pdf Retrieved August 10, 2019.

Kirkpatrick, M. (2017). Cops and urban youth find common ground: The Youth and Police Initiative has helped reduce big-city crime. Wall Street Journal, June 2.

Kleck, G., \& Jackson, D. (2016). What kind of joblessness affects crime? A national 
case-control study of serious property crime. Journal of Quantitative Criminology, 32, 489-513. DOI 10.1007/s10940-016-9282-0.

Knafo, S. (2016). A black police officer's fight against the N.Y.P.D. NY Times. https:// nyti.ms/2jVQZXA [https://perma.cc/F9CG-UPFQ].

Kochel, T. R., Parks, R., \& Mastrofski, S. D. (2013). Examining police effectiveness as a pre-cursor to legitimacy and cooperation with police. Justice Quarterly, 30, 895-925.

Kolb, D. A. 1984. Experiential learning: Experience as the source of learning and development. Englewood Cliffs, NJ: Prentice Hall.

Kutateladze, L., \& Lawson,V. Z. (2016). How bad arrests lead to bad prosecution: Exploring the impact of prior arrests on plea bargaining. Cardozo Law Review, $37,973$.

Law,V.(2011).Martori Farms:Abusive conditions at a keyWal-Mart supplier. Retrieved from www.truth-out.org $/$ index.php?option $=$ com $\% 5 \mathrm{fk} 2 \&$ view $=$ item $\&$ id $=1808$ : martorifarms-abusive-conditions-at-a-key-walmart-supplier, Retrieved October 23rd 2019.

Lawrence, S., \& McCarthy, B. (2013). What works in community policing? A best practices context for measure Y.The Chief Justice Earl Warren Institute on Law and Social Policy University of California, Berkeley School of Law.

Leiber, M., Nalla, M., \& Farnworth, M. (1998). Explaining juveniles' attitudes toward the police. Justice Quarterly, 15, 151-174.

Long, M. A., Cross, J. E., Shelley, T. O. C., \& Ivkovic, S. (2013). The normative order of reporting police misconduct: Examining the roles of offense seriousness, legitimacy, and fairness. Social Psychology Quarterly, 76(3), 242-267.

Lonsway, K., Wood, M., Fickling, M., De Leon, A., Moore, M., Harrington, C. P., \& Spillar, K. (2002). Men, women, and police excessive force: A tale of two genders. A Report for the National Center for Women \& Policing. Retrieved from http:// womenandpolicing.com/publications.asp January 14, 2020.

Lopez, G.(2016).Killings of police officers on duty are near record lows. Vox, retrieved from www.vox.com/identities/2016/8/13/17938238/police-officer-on-duty-deathskillings January 16, 2020.

Lord, A. (2019). www.ajc.com/news/national/here-why-police-don-shoot-woundthe-case-deadly-force/IV4ohtIm6r8FaEMj78u1bO/. Atlanta Journal Constitution.

Love-Craighead, A. (2016) Trauma-informed policing interview. www.vera.org/ events/see-justice/trauma-informed-policing-with-captain-altovise-love-craighead, retrieved October 23, 2019.

Lundman, R. J., \& Kaufman, R. L. (2003). Driving while black: Effects of race, ethnicity, and gender on citizen self-reports of traffic stops and police actions. Criminology, 41, 195-220.

McLaughlin, M.W. (2018). You can't be what you can't see: The power of opportunity to change young lives. Cambridge, MA: Harvard Education Press.

Maguire, E., \& Wells. W. (2009). Implementing community policing: Lessons from 12 agencies. Washington, DC: Community-Oriented Policing Services, U.S. Department of Justice.

Marinos, V., \& Innocente, N. (2008). Factors influencing police attitudes toward extrajudicial measures under the Youth Criminal Justice Act. Journal of Criminology and Criminal Justice, 50(4), 469489.

Maruschak, L. M., Berzofsky, M., \& Unangst, J. (2011). Medical problems of state and federal prisoners and jail inmates. Washington, DC: Bureau of Justice Statistics. 
Massoglia, M. (2008). Incarceration as exposure:The prison, infectious disease, and other stress-related illnesses. Journal of Health Social Behavior, 49(1), 56-71.

Mastrofski, S. D., Snipes, J. B., \& Supina,A.E. (1996). Compliance on demand:The public's response to specific police requests. Journal of Research in Crime and Delinquency, 33 , 269-305.

Mayors Innovation Project. (2017). www.mayorsinnovation.org/images/uploads/ pdf/21st_Century_Policing_Full_BB_final.pdf., retrieved August 11, 2019.

Meares, T. L. (2009). The legitimacy of police among young African American men. Faculty scholarship series (Paper 528). Electronic document retrieved from http:// digitalcommons.law.yale.edu/fss_papers/528 October 23, 2019.

Michelson, R. (2016). Why cops should pursue higher education: Earning a degree is what's best for your organization, your community and your profession. Police.com. Retrieved on April 5, 2020 from www.policeone.com/police-jobs-and-careers/ articles/why-cops-should-pursue-higher-education-zF6yJRfkQM4y56y

Miller, S. I., Forest K. B., \& Jurik, N. C. (2003). Diversity in blue: Lesbian and gay police officers in a masculine occupation. Arizona State University Men and Masculinities, 5(4), 355-385, doi: 10.1177/0095399702250841.

Miller, W. R., \& Rollnick, S. (2002). Motivational interviewing: Preparing people for change (2nd ed.). New York: The Guilford Press.

Mogul, J. L., Ritchie, A. J., \& Whitlock, K. (2012). Queer (in)justice: The criminalization of LGBT people in the United States. Boston, MA: Beacon Press.

Mogul, J. L., Ritchie, A. J., \& Whitlock, K. (2015). The ghosts of Stonewall: Policing gender, policing sex. https://truthout.org/articles/the-ghosts-of-stonewall-policinggender-policing-sex/, retrieved August 3, 2019.

Moore, S. E., Robinson, M.A.,Adedoyinc, A. C., Brooks, M., Harmone, D. K., \& Boamah, D. (2016). Hands up-Don't shoot: Police shooting of young black males: Implications for social work and human services. Journal of Human Behavior in the Social Environment, 26(3-4), 254-266, http://dx.doi.org/10.1080/10911359.2015.1125202.

Murphy, K., Tyler, T. R., \& Curtis, A. (2009). Nurturing regulatory compliance: Is procedural justice effective when people question the legitimacy of the law? Regulation $\mathcal{E}$ Governance, 3, 1-26.

Musumeci, N. \& Parascandola, R. (2014). Exclusive: Gun violence rises in Brownsville where cops see more shooting victims than any other precinct. NY Daily News, May 21.

NAFI (North American Family Institute) (2019). www.nafi.com.

NCTSN Fact Sheet (2009). www.nctsn.org/resources/child-sexual-abuse-fact-sheetparents-teachers-and-other-caregivers.

NCTSN (2011). www.nctsn.org/resources/trauma-and-families-fact-sheet-providers.

Neville, F. G., Goodall, C. A., Gavine, A. J., Williams, D. J., \& Donnelly, P. D. (2015). Public health, youth violence, and perpetrator well-being. Peace and Conflict:Journal of Peace Psychology, 21(3), 322-333, http://dx.doi.org/10.1037/pac0000081.

New York City Civilian Complaint Review Board. (2014). www.nyc.gov/html/ccrb/ html/news/reports.shtml, retrieved August 22, 2016.

Nirenberg, T. B., Bairda, J., Longabaugh, R., \& Mello, M. J. C. (2013). Motivational counseling reduces future police charges in court referred youth. Accident Analysis and Prevention, 53(1), 89-99. 
New York Civil Liberties Union. Stop-and-frisk. (2011). New York, NY: New York Civil Liberties Union.

New York Civil Liberties Union. (2015). Stop-and-frisk data. www.nyclu.org/content/ stop-and-frisk-data.

O’Sullivan, T. L., Corneil, W., Kuziemsky, C. E., \& Toal-Sullivan, D. (2015). Use of the structured interview matrix to enhance community resilience through collaboration and inclusive engagement. Systems Research \& Behavioral Science, 32(6), 616-628.

Papachristos, D. M., \& Kirk, D. S. (2016). Police violence and citizen crime reporting in the black community. American Sociological Review, 81(5), 857-876. https://DOI. org/10.1177/0003122416663494.

Pask, G. (1975). The cybernetics of human learning and performance: A guide to theory and research. London: Hutchinson Educational.

Pask, G. (1979). A conversation theoretic approach to social systems. In F. Geyer \& J. van der Zouwen (Eds.), Sociocybernetics (pp. 15-26). Amsterdam: Martin Nijholf.

Payton, J. W., Wardlaw, D. M., Graczyk, P. A., Bloodworth, M. R., Tompsett, C. J., \& Weissberg, R. P. (2000). Social and emotional learning: A framework for promoting mental health and reducing risk behaviors in children and youth. Journal of School Health, 70(5), 179-185.

Pieterse, A. L., Carter, R. T., Evans, S. A., \& Walter, R. A. (2010). An exploratory examination of the associations among racial and ethnic discrimination, racial climate, and trauma-related symptoms in a college student population. Journal of Counseling Psychology, 57(3), 255-263.

Pogarsky, G., \& Piquero, A. R. (2004). Studying the reach of deterrence: Can deterrence theory help explain police misconduct? Journal of Criminal Justice, 32(4), 371-386.

Poteyeva, M., \& Sun, I.Y. (2009). Gender differences in police officers' attitudes: Assessing current empirical evidence. Journal of Criminal Justice, 37, 512-522.

President's Task Force on 21st Century Policing. (2015). Final Report of the President's Task Force on 21st Century Policing. Washington, DC: Office of Community Oriented Policing Services.

Rabe-Hemp, C. E. (2008). Female officers and the ethic of care: Does officer gender impact police behaviors? Journal of Criminal Justice, 36, 426-434.

Rabe-Hemp, C. E., \& Schuck, A. M. (2007).Violence against police officers: Are female officers at greater risk? Police Quarterly, 10, 411-428.

Rabois, D., \& Haaga, D.A.F. (2002). Facilitating police-minority youth attitude change: The effects of cooperation within a competitive context and exposure to typical exemplars. Journal of Community Psychology, 30, 189-195.

Raymond v. the City of New York. (2015). https://casetext.com/case/raymondv-city-of-ny-2.

Rengifo,A., \& Fratello,J. (2014). Looking at stop-and-frisk and beyond using a NewYork city sample. Youth Violence and Juvenile Justice, 13(4) DOI:10.1177/1541204014547591.

Richardson, L. S., \& Carbado, D. W. (2018). Book review: The black police: Policing our own. Harvard Law Review, May 10.

Richardson, L. S., \& Goff, P.A. (2014). Interrogating racial violence, Ohio State University of Criminology, 12, 115-152. 
Ricketts, J. C., \& Rudd, R. D. (2002). A comprehensive leadership education model to train, teach, and develop leadership in youth. Journal of Career and Technical Education, 19(1), 7-17.

Ridgeway G. (2007). Analysis of racial disparities in the New York police department's stop, question, and frisk practices. Santa Monica, CA: Rand Corporation.

Roberts, D. E. (1999). Foreword: race, vagueness, and the social meaning of ordermaintenance policing. Journal of Criminal Law, 89(3), 775-836.

Rosenbaum, D., \& Lawrence, D. S. (2017). Teaching procedural justice and communication skills during police-community encounters: Results of a randomized control trial with police recruits. Journal of Experimental Criminology, 13, 293-319 DOI 10.1007/ s11292-017-9293-3.

Rosenberg, H. J., Vance, J. E., Rosenberg, S. D., Wolford, G. L., Ashley, S. W., \& Howard, M. L. (2014). Trauma exposure, psychiatric disorders, and resiliency in juvenilejustice-involved youth. Psychological Trauma: Theory, Research, Practice, and Policy, 6(4), 430-437. https://doi.org/10.1037/a0033199.

Rydberg, J. \& Terrill,W. (2010). The effect of higher education on police behavior. Police Quarterly, 13(92), DOI: 10.1177/10986111093573252010.

Sakuma, A. (2016). Taser vs. gun: Why police choose deadly force despite non-lethal options. Bloomberg News, September 29.

Sampson, Robert J. (2012). Great American city: Chicago and the enduring neighborhood effect. Chicago: University of Chicago Press.

Santos, F. (2007). In a room, police and youths talk, and maybe see their similarities. New York Times, June 29.

Sarre, R., \& Langos, C. (2014). Policing young people: can the notion of police legitimacy play a role? Journal of the Institute of Justice \& International Studies, 13, 1-10.

Schuck, A. M., \& Rabe-Hemp, C. (2007). Women police. Women \& Criminal Justice, 16, 91-117.

Schuck, A. M. (2013). A life-course perspective on adolescents' attitudes to police dare, delinquency, and residential segregation. Journal of Research in Crime and Delinquency, 50(4), 579-607.doi:10.1177/0022427813481977.

Schnittker J. A. (2007). Enduring stigma: the long-term effects of incarceration on health. Journal of Health and Social Behavior, 48(2), 115-130.

Schuck, A. M. (2014). Differences in policing: testing hypotheses from the performance and disruption perspectives. Feminist Criminology, 9(2) 160-185, DOI: 10.1177/1557085113520033fcx.

Schwartz, K., Alexander, A. O., Lauc, K. S. L, Hollowayd, E. D., \& Aalsmaa, M. C. (2017). Motivating compliance: Juvenile probation officer strategies and skills. Journal of Offender Rehabilitation. 56(1), 20-37, http://dx.doi.org/10.1080/10509674.2016.1257532.

Seemiller, C.A. (2018). Competency-based model for youth leadership development. Journal of Leadership Education, 17(1), 56-72.

Sewell, A. A., \& Jefferson, K. A. (2016). The health effects of invasive police encounters in New York City. Journal of Urban Health: Bulletin of the New York Academy of Medicine, 93, doi:10.1007/s11524-015-0016-7.

Sharkey, P. (2018). Uneasy peace: The great crime decline, the renewal of city life, and the next war on violence, (1st edition). New York: WW Norton \& Co.

Shaw, C. R., \& McKay, H. D. (1972). Juvenile delinquency and urban areas. Chicago: University of Chicago Press. 
Silva, S. M., \& Samimi, C. (2018). Social work and prison labor: A restorative model. Social Work. 63(2), 153-160. doi: 10.1093/sw/swy009.

Slutkin, G. (2013). Violence is a contagious disease. Contagion of Violence Workshop Summary. Institute of Medicine and National Research Council. Retrieved from http://cureviolence.org/wp-content/uploads/2013/12/IOM-Chap-9.pdf.

Smith, C. (2018). http://nymag.com/intelligencer/2018/03/the-crime-fightingprogram-that-changed-new-york-forever.html, retrieved January 8, 2020.

South, J., Giuntoli, G., \& Kinsella, K. (2017). Getting past the dual logic: findings from a pilot asset mapping exercise in Sheffield, UK. Health \& Social Care in the Community, 25(1), 105-113.

Staggers-Hakim, R. (2016). The nation's unprotected children and the ghost of Mike Brown, or the impact of national police killings on the health and social development of African American boys. Journal of Human Behavior in the Social Environment, 26(3-4), 390-399.

Stein, L.A., Soenksen, S. Martin, R. A., Lebeau, R., \& Golembeske, C. (2013). Ethnicity as a moderator of motivational interviewing for incarcerated adolescents after release. Journal of Substance Abuse Treatment, 45(4), 370-375.

Stewart, E. A., Baumer E. P., Brunson, R. K., \& Simons, R. L. (2009). Neighborhood racial context and perceptions of police-based racial discrimination among black youth. Criminology, 47(3), 847-887.

Stoudt, B. G., Fine, M, \& Fox, M. (2011). Growing up policed in the age of aggressive policing policies. New York Law School Law Review. Electronic draft copy retrieved March 23, 2015 from www.indiana.edu/ atlantic/wp-content/uploads/2011/11/ Stoudt-Fine-Fox-Growing-Up-Policed.pdf, retrieved January 3, 2018.

Subhas, N., \& Chandra, A. (2004). Baltimore city Police Athletic League assessment study. Center for Adolescent Health Johns Hopkins Bloomberg School of Public Health.

Substance Abuse and Mental Health Services Administration. (2016). Trauma Informed Principals and Practice.

Sue, D., \& Sue, D. (2012). Counseling the culturally diverse: Theory E practice. Hoboken, NJ: John Wiley \& Sons, Inc.

Suter, J., \& Bruns, E. J. (2008). A narrative review of wraparound outcome studies. In E. J. Bruns \& J. S. Walker (Eds.), The re-source guide to wraparound. Portland, OR: National Wraparound Initiative, Research and Training Center for Family Support and Children's Mental Health.

Sunshine, J., \& Tyler,T. R. (2003). The role of procedural justice and legitimacy in shaping public support for policing. Law \& Society Review, 37, 513-548.

Surico, J. A. (2016). Former cop describes racist police quotas in New York. Vice, www. vice.com/en_us/article/yvx8v7/a-former-cop-describes-racist-police-quotas-innew-york [https://perma.cc/RS2R-98GV], retrieved July 11, 2019.

Tankebe, J. (2013).Viewing things differently: The dimensions of public perceptions of police legitimacy. Criminology, 51, 103-135

Terrill, W. (2005). Police use of force: A transactional approach. Justice Quarterly, 22(1), 107-138.

Thompson, R.A. (2003). Career experiences of African American police executives: black in blue revisited. El Paso, TX: LFB Scholarly Publishing LLC. 
Thurman, Q. C., Giacomazzi, A, \& Bogen, P. (1993). Research note: Cops, kids, and community policing - an assessment of a community policing demonstration project. Crime \& Delinquency, 39(4), 554-564.

Tyler, T. R., Fagan, J., \& Geller, A. (2014). Street stops and police legitimacy: Teachable moments in young urban men's legal socialization. Journal of Empirical Legal Studies, 11, 751-785.

Unnever, J. D., \& Gabbidon, S. L. (2011). A theory of African American offending: Race, racism, and crime. New York: Taylor \& Francis.

Van Manen, M. (2016). Phenomenology of practice: Meaning giving methods in phenomenological research and writing. New York, NY: Routledge.

Van Wormer, K. (1981). Are males suited to police patrol work? Police Studies, 3, 41-44.

Vandenberg, V. (2006). History of wraparound and systems of care. Retrieved May 9, 2006, from www.vroonvdb.com/about_wraparound.html.

Vera Institute of Justice. (2016). www.vera.org/research/trauma-informed-policing, retrieved August 1, 2019.

Voisin, D., Harty, J., Dong, K., Elsaesser, C., \& Takahashi, L. (2017). Assessing the relationship between parental influences and wellbeing among low income African American adolescents in Chicago. Child E Youth Care Forum, 46(2), 223-242.

Wadman, R. C., \& Ziman, S. M. (1993). Courtesy and police authority. FBI Law Enforcement Bulletin, 62, 23-23.

Walters, S. T., Alexander, M., \& Vanbenschoten, S. (2008). Motivational interviewing training in criminal justice: Development of a plan. Federal Probation, 72(2), 61-66.

Watts, R., \& Washington, H. (2013). Evaluability study of Youth Police Initiative. Office of Juvenile Justice and Delinquency and Probation grant.

Weaver, R. D., and Campbell, D. (2015). Fresh start: A meta-analysis of aftercare programs for juvenile offenders. Research on Social Work Practice, 25(2), 201-212.

John E. Eck, Weisburd, D., Telep, C. W., \& Hinkle, J. C. (2010). Is problem-oriented policing effective in reducing crime and disorder? findings from a Campbell systematic review. Criminology \& Public Policy, 9(1), 139-172.

Weiser, B. (2017). New York City to pay up to $\$ 75$ million over dismissed summonses. New York Times, https://nyti.ms/2jR44V5 [https://perma.cc/GT25-RP2L].

Weiser, B. (2019). Kalief Browder's suicide brought changes to Rikers. Now it has led to a \$3 Million settlement. New York Times.

Weichselbaum, S. (2018). How a 'Sentiment meter' helps cops understand their precincts police in LA, NYC, and beyond are using software from Elucd to figure out to measure the feelings of the people they protect. www.wired.com/story/elucdsentiment-meter-helps-cops-understand-precincts/, retrieved January 8, 2020.

Weitzer, R. (1999) Citizens' perceptions of police misconduct: Race and neighborhood context. Justice Quarterly, 16, 819-846.

Wheller, L., Quinton, P., Fildes, A., and Mills, A. (2013). The Greater Manchester Police Procedural Justice Training Experiment: The impact of communication skills training on officers and victims of crime. UK: College of Policing.

Wickes, R., \& Sydes, M. (2017). Social Disorganization Theory. www.oxfordbibliographies.com/view/document/obo-9780199756384/obo-9780199756384-0192. xml\#obo-9780199756384-0192-bibItem-0010, retrieved January 9, 2020. 
Wilkins,V. M., \& Williams, B. N. (2008). Black or blue: Racial profiling and representative bureaucracy. Public Administration Review, 68(654), 660-661.

Wolfe, S. E., \& Piquero, A. R. (2011). Organizational justice and police misconduct. Criminal Justice and Behavior, 38(4), 332-353.

Wood, A. R., Wood, R. J., \& Taylor, S. M. (2012). Becoming more therapeutic: Motivational interviewing as a communication style for paraprofessionals in juvenile justice settings. In E. L. Grigorenko (Ed.) Handbook of juvenile forensic psychology and psychiatry (pp. 239-251). New York: Springer Science.

Wooten, H. B. (2000). Public safety, crime reduction, and crime prevention: officers get it, will managers follow? Corrections Management Quarterly, 4(2), 34-40.

Worden, A. P. (1993). The attitudes of women and men in policing:Testing conventional and contemporary wisdom. Criminology, 31, 203-224.

Woyach, R. B., \& Cox, K. J. (1997). Principles for youth leadership development programs. Leadership Link. Columbus $\mathrm{OH}$ : The Ohio State University Leadership Center. 